INDEPENDENT JOURNAL OF MANAGEMENT \& PRODUCTION (IJM\&P)

http://www.ijmp.jor.br

v. 12, n. 4, May-June 2021

ISSN: 2236-269X

DOI: 10.14807/ijmp.v12i4.1340

\title{
DISTRIBUTION CHANNELS (DC) IN THE TECHNOLOGICAL INDUSTRY - IDEAS FOR IMPROVEMENT IN ARGENTINA
}

\author{
Leandro A. Viltard \\ Pontificia Universidad Católica Argentina (Buenos Aires), \\ Doctorado en Diseño y Comunicación y Facultad de Ciencias \\ Econômicas,Universidad de Palermo, \\ Universidad Nacional del Comahue, Argentina \\ Universidad del Pacífico, Ecuador \\ E-mail: lviltard@yahoo.com.ar \\ Leandro Viltard \\ Universidad Nacional del Comahue, Argentina \\ E-mail: leliviltard@yahoo.com.ar \\ Submission: 5/4/2020 \\ Revision: 6/3/2020 \\ Accept: 8/15/2020
}

\section{ABSTRACT}

For many years, the DC operation -covering massive sales and value added solutions- have been a reality in the Argentinean technological industry. Manufacturing companies have used them as a central part of their commercial growth/value added strategies to provide greater geographical coverage and adequacy to the products/services offered. As a result, this work shows different DC facets of this environment and possible improvement aspects. Management focus could bring better performance levels for the organizations that configure this complex and exciting industry. The hypothesis of this study -which was corroborated- is that there are aspects that can be improved in the DC operation of the Argentinean technological industry, bringing value added and sustainable growth to the companies' network. Main findings of this work reveal that long DC and hybrid models are mostly used by manufacturers because they improve commercial reach, final customers' solutions and purchase experience, providing the highest possible flexibility and profitability. It also requires cost optimization, channel efficiencies and vertical conflicts reduction. In addition, there are challenges connected to: a) the whole DC network value understanding and the optimal channel level mix, b) customer demand generation, 
DOI: $10.14807 /$ ijmp.v12i4.1340

c) the technology/cloud-based businesses and the SMB (Small Medium Business) that need more personalization and value added focus, d) remote channels/online platforms versus physical channels, e) the Opportunity Registration process as a way to protect the DC investment in certain key customers, and f) training opportunities, among others. The final objective referrers to get away from imitation and commoditization, proposing a unique value proposition for which strategy and marketing plans should create long term customer value. Finally, best practices are remarked as a way to evolve to new performance levels. The study is exploratory-descriptive, with a qualitative methodology, and it is supported with a bibliographical and an empirical analysis.

Keywords: distribution; channel; business partners; wholesalers; technological industry

\section{INTRODUCTION}

For many years, the DC operation -covering massive sales and value added solutionshave been a reality in the Argentinean technological market. Manufacturing companies or brands -as they are called in this industry- have used them as a central part of their commercial strategies in order to provide greater geographical coverage and adequacy to the products/services offered.

In connection with the above, this work finds its fundamental motivation in the opportunities that can be found from the appropriate management of this operation in Argentina and its impact on sustainable competitive advantages generation. In this highly competitive context developed in recent years, it is possible to observe certain challenges and inconsistencies between the expectations in both types of organizations regarding their commercial relationship and training programs, such as:

- Market coverage and conflicts: in front of the manufacturer's impossibility to have adequate market coverage all over Argentina, some experts remark that DC are a fundamental commercial chain link in order to reach end customers more effectively. In this sense, Miquel Perris et al. (2008) and Muñiz González (2014) assert that hybrid models and long channels ${ }^{1}$ are mostly used in this industry as they provide a better coverage at a lower cost, despite what specialists said that could bring potential

${ }^{1}$ In order to reach end customers hybrid models include a direct attention to some of them and an indirect one to others. In addition, long channels require manufacturers, wholesalers and DC. 
DOI: 10.14807/ijmp.v12i4.1340

relationship/profitability conflicts between the manufacturer and the DC network (called vertical channel conflict) as -sometimes- they are immerse in their own paradigms and problematics.

- Customer's migration to more profitable DC: Caylar et al. (2014) establish the need to carry out a specific plan that allows customers to migrate to DC that are more profitable for the manufacturer, coinciding with the specialists that were consulted.

- SMB approach: CDs have been and will be important to the Small Medium Business (SMB). Avrane-Chopard et al. (2014) have deepened this concept establishing that -in 2015- this market will represent annual revenues of USD 28 billion, with a net profit of approximately USD 3.5 to 4 billion. At the same time and since the DC have their origin in a more standardized world the author argues that the manufacturers' challenge is to provide them with adequate training on value added alternatives. Berland and Furtado (2015) and Duarte et al. (2015) coincide on the need for new value added practices to respond to an increasing challenging market demand, which should be supported on distribution chain and coverage growth, and on online sales/support platforms.

- Incentives and promotions: According to what was verified through the opinion of some experts, promotions and incentives had been important to generate demand in the short and medium term. In this sense, it becomes a priority to adequately implement these tools and to improve the communication between both organizations so that they can cover the greatest number of market requirements.

- Comprehensive training/educational programs: agreeing with the interviewed experts, Islas Murguia and Macias Correa (2013) point out that the training sessions should be tailor made and go beyond technical matters, including commercial/management topics and tools that will allow a better products/services value transmission and set aside from market commoditization.

As a result, improvement opportunities become an objective in this industrial sector and specifically of this work, spanning from business to training/educational issues. The final goal connects with organizational growth, value added and sustainability.

The hypothesis of this study indicates that there are aspects that can be improved in the Argentinean technological industry DC operation, bringing value added and sustainable growth to their network. 
DOI: $10.14807 /$ ijmp.v12i4.1340

Therefore, the main objective of this work refers to the study of the current DC operation in the technological arena, identifying areas for improvement in their relationship with manufacturing companies in Argentina.

The following questions have allowed guiding this investigation:

- What are the factors that favor the manufacturer-DC relationship and profitability?

- Are there any improvement possibilities in the Argentinean technological market?

It is important to express some clarifications/limitations in order to give a better understanding of this study:

- Due to the lack of studies that make specific reference to this specific matter, it is observed an impossibility to analyze specific theories regarding DC within the technological industry. For this reason, the conceptual framework was built from a broader point of view, with national and international authors/publications. It includes organizational growth; value added alternatives; strategy, marketing, and training; and improvement opportunities in those areas.

As a result, the Theoretical Framework that was utilized is the one that was judged necessary to support the present study, although it could be found other authors and publications that may complement it. Also, classical authors were included as they present an updated perspective on the studied matters.

- The field work is based on the objective and the hypothesis raised. Due to the little theoretical DC information in the technological arena, mostly in Argentina, the study is complemented with a field work that includes three interviews with industry specialists. This technique is the one that was judged as appropriate for this investigation, although there could be perform other ones.

In any case, a certain reservation is presented regarding the particularities that this complex market presents in countries like Argentina.

- The conclusions are connected with the Theoretical Framework and field work performed.

The prior clarifications/limitations were not an impediment to reach appropriate conclusions and comply with the hypothesis and the objective of this work. 
DOI: $10.14807 /$ ijmp.v12i4.1340

The study is exploratory-descriptive, with qualitative methodology. In addition, it is holistic because it contemplates a wide configuration in which the studied object is located.

It is used a non-experimental design and -among them- transversal, as the information was gathered at a certain point in time.

The analysis unit is related to international and national distribution channels of this industry, in general, but specifically to the Argentinean network. The characteristics of these companies vary in aspects such as the Head Office and branches location, size (in terms of quantity of personnel and revenues, among others) and the countries in which they operate.

The criteria used to select the sample is non probabilistic, intentional and directed. Being a qualitative investigation, the sample size has not implied a scope limitation.

Both, a bibliographical and an empirical study were performed. The bibliographical research implied data collection and the analysis of the information obtained through relevant secondary sources, mainly international authors and publications. The field work is composed by interviews -made through Skype- to three different specialists who had a vast experience in the regional industry and in Argentina. This analysis tried to deepen in the main characteristics and knowledge that emerged in this industry.

The response unit is constituted by the experts that were interviewed in the field work.

It is clarified that it is not possible to generalize the findings that are presented due to the fact that this research responds to a qualitative design, with a non-probabilistic, directed and intentional sample. Anyway, the final conclusions can be useful for decision making.

This research was performed from Aug., 2019 to May 2020, and was carried out in Buenos Aires, Argentina.

As a result of this study, it is highlighted that the hypothesis was corroborated and the objective verified.

\section{THEORETICAL FRAMEWORK}

There were identified certain important topics to support technically and theoretically this research, which refer specifically to DC and some related matter that were identified.

\subsection{Distribution Channels (DC)}

For manufacturing firms, DC are a fundamental way to reach end customers in a timely manner and with an adequate support. So, different elements will be studied in connection to 
DOI: $10.14807 /$ ijmp.v12i4.1340

the DC understanding; the benefits, challenges and possibilities that they offer; and -finallytheir importance for organizational growth and sustainability.

\subsubsection{DC understanding}

Currently, many technological companies use DC as a sales strategy for their products/services. According to Selva and Conde (2013) and Logenecher et al. (2012), they represent the conduit that is chosen to deliver products -in the most complete, efficient and economical way- from the production company to the final consumers.

At the discretion of Miquel Peris et al. (2008), the DC can be classified in three ways: according to their length, to their sales technology and to their organizational form. Due to the scope of the present study, the length classification will be considered, especially since it is the most widely used in the technological market, having three fundamental actors:

- Direct Channels: implies that the manufacturer and the final consumer are connected directly. It is mostly used in the services market.

- Short Channels: consists in three levels: manufacturer, distributor and final consumer. It is used when the offer is at the manufacturer or distributor level.

- Long Channels: includes four levels: manufacturer, wholesale distributor, retail distributor and final consumer. It is used with clients that are difficult to reach, so a greater capillarity is needed.

González (2014) remarks that:

- Long channels are mostly used in the technological arena since they cover an important commercial dimension in this market.

- Property transfer becomes a key factor to be considered as a channel. Therefore, the main fact is that ownership must change hands.

- There are some questions that must be asked when defining what type of DC is most suitable for a manufacturing firm, namely:

o What product control is intended to be carried out?

o Will you reach all corners of the country?

o Will you intervene on the final price fixing?

o Will you be involved in all promotional activities? 
DOI: $10.14807 /$ ijmp.v12i4.1340

o Does your company have great financial capacity?

o Is there a large commercial team available?

o Is there an interest to go into other countries directly?

o Are the logistics infrastructure characteristics known?

o What level of information is desired?

o Is there the intention to be on the market 365 days and 24 hours?

The author concludes that the best DC design and operation will depend on the appropriate answer to the preceding questions. Failure to do so implies leaving free paths to competitors and making it impossible to generate competitive advantages.

A particular consideration should be put on the new DC that emerge in every market. In this sense, Caylar et al. (2014) highlight -among the many challenges that this sector hasthe need to make the best use of the new DC, generating a coherent and concrete plan for them. In addition, they say that:

- At least, $70 \%$ of the customers have information from two channels and then they compare conditions on product, price and availability, among other variables.

- $50 \%$ of the customers search for information through one channel and then buy through another.

\subsection{2. $\quad$ DC benefits, challenges and possibilities}

Caylar et al. (2014) propose some DC benefits when the right channel strategy is implemented:

- Solutions' sales, not solitary products: company revenues can grow exponentially when the DC can add value to the customer.

- Cost optimization: choosing the most convenient DC for each business.

- Consumer experience improvement: when integrating DC' feedback.

- Channel efficiency: if there is a clear differentiation in terms of brand.

Also and as product commoditization increases, the authors indicate that there are diverse challenges that must be faced: a) remote channels, which are attracting more sales through online platforms, and b) call centers, which are being used by manufacturers to make 
DOI: $10.14807 /$ ijmp.v12i4.1340

more sales. But, physical channels have still dominance in the market as many customers prefer them because they offer face to face attention and product testing at the time of purchase.

In turn, they propose a series of questions that become important in order to capitalize the potential of a manufacturer's DC:

- What is the DC economic performance in a variety of transactions?

- How does a firm define a correct mix of channel types that promote sales, services and access to information?

- What would be the implications of changing that channel mix?

- What would be the correct firm approach to reach the desired mix?

- What would be the barriers that would prevent a customer from taking the most efficient DC for the company?

- How can these barriers be neutralized and how can the company help the customer to be able to do it?

Finally, the authors offer certain possibilities to increase business growth at DC level:

- DC network value definition: each manufacturer must establish requirements and proposals that each DC must have in conjunction with the whole channels itself.

- Top channels value added identification: products/services must be associated to DC profits and possibilities. In this sense, it must be known the value added that top channels provide to the business.

- Optimal channel level mix and sales: it is required a 3-year plan that must contain a channel business map, areas for profitability and investments improvements that will be made for brand development and growth.

- End customers and collection of product experiences information: product customer experiences must be clearly identified as well as the barriers that prevent their adoption.

- Specific actions on channel mix: they must be reflected in a plan, establishing concrete steps so that the customer can migrate towards the manufacturer's optimal and most profitable channels. Also, it is important to described the incentives that the channel will receive and the infrastructure that will be provided, among others.

\subsubsection{DC importance for firm's growth}


DOI: $10.14807 /$ ijmp.v12i4.1340

According to Avrane-Chopard et al. (2014), Small and Medium Businesses (SMB) must be considered a key partner for business growth in the technological arena, especially in the cloud-based business. Koulopoulos (2014) add that the cloud concept is not only related to technology but to a 21st century megatrend, where physical computers are replaced by virtual computers.

In this regard, Avrane-Chopard et al. (2014) provide SMB information that is highly representative for this sector, as follows:

- By 2015 and worldwide, this market will offer a revenue opportunity of USD 28 billion with a net profit of between USD 3.5 and 4 Billion (14\% approximately), which will represent half of the total cloud market. This figure takes greater significance since many companies focus on their most frequent customers, leaving aside the real growth opportunities that represent new customers and new markets.

- $\quad$ SMB have a need for higher personalization levels, although they have more limited resources than large companies. Without a doubt, this is something that organizations must take into account when launching their offers to the market.

- In this scenario, the relationship between the firm and its business associates must be rethought. On the one hand, the channels that provide value added come from a more standardized world and their knowledge has never been as profound as it is needed. As for the firm's perspective, whenever a new and disruptive business is being considered it represents a great opportunity for competitive advantages in that market.

Reaffirming the precedent concepts, Berland and Furtado (2015) indicate that:

- The practices and approaches that technological companies have carried out with their DC have already been left behind and new ones must emerge. They establish that common practices, such as gathering market information and reviewing price gaps with main competitors, have less chances of producing a competitive advantage.

- In 25 firms in which they implemented new practices, they obtained positive results selling products over market prices and with better margins. Also, these firms applied more analytical tools, which gave them the advantage of having more elasticity in their prices when compared to their competitors. 
DOI: $10.14807 /$ ijmp.v12i4.1340

New ways and efficiencies have taken place in this type of structures. In this sense, Duarte et al. (2015) say that -in the early 2000s- technological companies grew their distributors' network exponentially, and then began to explore sales through online platforms and other direct ways of reaching customers. At the same time, they establish that -for the last years- the distributor schemes are being revised as worldwide CEOs and Directors have become more aware of market penetration strategies. So, there are two fundamental questions that the authors raise:

- Is it necessary to maintain -in all the businesses that the firm carries out- the high costs of adding a DC?

- Are there ways to optimize the DC business presence?

Additionally, they consider certain trends that are currently happening, which serve when reviewing the DC's scheme that is available, as follows:

- Product cross-selling practices and value added focus per transaction.

- Productivity and cost efficiency optimization in each DC, especially in those markets where greater competition is observed.

- Customers are increasingly more informed, posing two basic challenges at DC level: to innovate and to best satisfy customer needs.

- Using the correct DC strategy implies to produce competitive advantages as capillarity and penetration increase considerably when the strategy is the correct one.

- The DC represent a market driving force in the long-term customers relationship, influencing their decisions. Also, that the DC are reinventing their role since they intend to have clear the customer purchasing behaviors in order to better predict their needs.

Contributing to the prior considerations, Del Molino et al. (2014) express that firms that have DC and customer management as priorities have grown their net sales results $3 \%$ to $6 \%$, when compared to their competitors. In their study, which included 141 dispersed organizations worldwide, only $24 \%$ could demonstrate that they had those priorities, of which only $7 \%$ turned out to be multinationals. As a result, they suggest the following strategies:

- Invest the greatest amount of resources in the businesses that produce the highest income: Resources should be directed towards the fastest growing businesses in order to generate a special focus and an avid chain. 
- Generate collaborative relationships with our clients and distribution channels: successful companies confront customers on -at least- seven important issues, including innovation and promotions, among others. On the other hand, laggard companies only confront them on a maximum of three issues.

- Use effectively the data produced from market actions that are carried out (such as promotions and marketing events, among others): take advantage of the largest number of analytical paths that can provide useful tools for decision-making.

- Increase sales, using efficient and innovative models to reach customers: leading companies review their DC strategy annually/quarterly, understanding if those they own are correct, adding new or removing others.

In this section, were revealed different elements that show the importance of having an efficient DC chain that provide capillarity and more customer reach. Particularities are raised regarding the technology industry, as well as benefits and challenges. It is observed that companies that develop a channel network focused on what their business can offer, customer advantages and value added are more successful. Finally, conflicting visions on new ways of reaching the market were addressed.

As a summary, the following Figure 1 shows the different aspects and particularities on DC analyzed:

\begin{tabular}{|c|c|}
\hline Concept & Description \\
\hline $\begin{array}{l}\text { DC understanding, } \\
\text { classification and } \\
\text { new channels }\end{array}$ & $\begin{array}{l}\checkmark \text { Used as a sales strategy to deliver products from the production company to final } \\
\text { consumers. } \\
\checkmark \text { Classification according to their length: direct, short and long channels. Long channels are } \\
\text { mostly used in the technological arena as they cover an important commercial dimension. } \\
\checkmark \text { Make the best use of the new DC that emerge. }\end{array}$ \\
\hline $\begin{array}{l}\text { DC benefits, } \\
\text { challenges and } \\
\text { possibilities }\end{array}$ & $\begin{array}{l}\checkmark \text { Benefits: solutions' sales, cost optimization, consumer experience improvement, and } \\
\text { channel efficiency. } \\
\checkmark \text { Challenges: remote channels with online platforms and manufacturers with call centers. } \\
\checkmark \text { Physical channels are still important because of face to face attention and product testing } \\
\text { at the time of purchase. } \\
\checkmark \text { Possibilities: DC network value definition; top channels value added identification; } \\
\text { optimal channel level mix and sales; end customers and product experiences information } \\
\text { collection; and specific actions on channel mix. }\end{array}$ \\
\hline $\begin{array}{l}\text { DC importance for } \\
\text { business growth }\end{array}$ & $\begin{array}{l}\checkmark \text { Opportunities in SMB and technology/cloud-based business. } \\
\checkmark \text { SMB need for personalization and value added in their offers. } \\
\checkmark \text { Common practices and approaches must be reviewed. New ones must emerge, ex.: } \\
\text { sophisticated analytical tools, on line platforms and direct ways of reaching customers. } \\
\checkmark \text { Awareness on market penetration strategies and on DC optimization/additional costs they } \\
\text { add to a business. } \\
\checkmark \text { New trends/approaches: cross-selling; value added; productivity and cost efficiencies; } \\
\text { innovation; customer behavior and satisfaction; and competitive advantage focus. } \\
\checkmark \text { Suggested strategies for DC: adequate investments, collaborative relationships, market } \\
\text { data for decision making, and reach customers in novel ways. }\end{array}$ \\
\hline
\end{tabular}

Table 1: Distribution Channels (DC)

Source: Own 
DOI: $10.14807 /$ ijmp.v12i4.1340

\subsection{Business factors that influence the technological industry}

In this section, different fundamental elements that were identified and support this investigation are covered, specifically organizational growth, value creation, corporate strategy, marketing and best practices, which may help to identify theoretical elements needed to achieve new performance levels.

\subsubsection{Organizational growth}

Growth becomes vital for company's health, coming from different sources. Thus and in accordance with Balderrama and Arán (2007), growth has its origin in the following different approaches:

1) Along the value chain, for which it is fundamental the vertical integration concept. It is understood as businesses that belong to the same firm's original business value chain. There are different reasons for vertical integration such as the internalization of key business activities and ideas that contribute to product quality. To achieve a successful vertical integration, it is required the firm's flexibility for change management. As an example, is cited Nintendo -Asiatic firm dedicated to video games and consoles- which had a tremendous annual growth of 90\% between 1984 and 1992. Their success factor was based on following equilibrium between internal and external developers. Examples of successful internal developments are Donkey Kong and Super Mario Bros, among others.

2) New geographies, having as a result greater economies of scale and increased international market sales. For example, Wal-Mart -the USA firm- has only $20 \%$ of sales outside their territory.

3) New business diversification. Walt Disney World, the USA firm born in 1923 as a film producer, grew between 1994 and 2000 at a 25\% average -with annual revenues of 25 billion dollars- thanks to other additional activities as:

- Animated films elaboration and production.

- Merchandising stores related to the themes of his films.

- Cruise fleet operation that depart from Florida.

- Theme parks in Florida, Europe and Japan.

- Television channels, such as ESPN, Disney Channel and ABC. 
DOI: $10.14807 /$ ijmp.v12i4.1340

One of the fundamental questions that the authors raise refers to growth possibilities from the non-traditional business, proposing the following meeting points:

- Almost all businesses shared the same characters; the most famous were Mickey Mouse, Donald Duck, and the Pluto dog.

- The characters that emerged from their films and cartoons nurtured each one of these divisions and were present in the stores as merchandising. Also, they interacted with tourists on their cruises and theme parks, as well as being the protagonists in their television channels.

- The characters were the ones that made Disney different since they represented diverse aspects of society; for instance, values, American ingenuity and family entertainment.

In contrast, the authors give examples of firms that have decided to remain loyal to a single business unit, without diversifying as Wal-Mart, which has remained specialized and faithful to its distribution business. Its growth has been of $20 \%$ annual average in the last 20 years.

4) Merger and acquisitions with/of other companies, accessing to new resources and customers that were foreign to the buying firm. These resources could be internal (ex.: technologies and deposits) or external (ex.: customers and vendors). As an example and between 1995 and 2001, the Spanish firm Telefónica had an annual growth of 27\% through different acquisitions (ex.: Telesp in Brazil).

5) Strategic alliances, referred to:

- Complementary alliances: collaboration agreements in pursuit of common interests, accessing to resources/capacities that the firm did not currently own.

- Addition alliances: contributes to expanding coverage and penetration in their respective markets.

- Mutual development alliances: develops a synergy to achieve a common objective.

It is said that there is no type of alliance that is more convenient than another, having some benefits (like quick access to capacities and resources and risks reduction) and inconveniences (management, and faster learning and business control from one of the partners). 
DOI: $10.14807 /$ ijmp.v12i4.1340

From what is stated in this section, it is observed that firms' growth strategies connect with value creation, which can come from the different sources that were previously detailed. Obviously, many of these growth strategies can be implemented through skilled DC that help with their offers to produce a valuable market differentiation.

The following Figure 2 presents the fundamental concepts pointed out in this section:

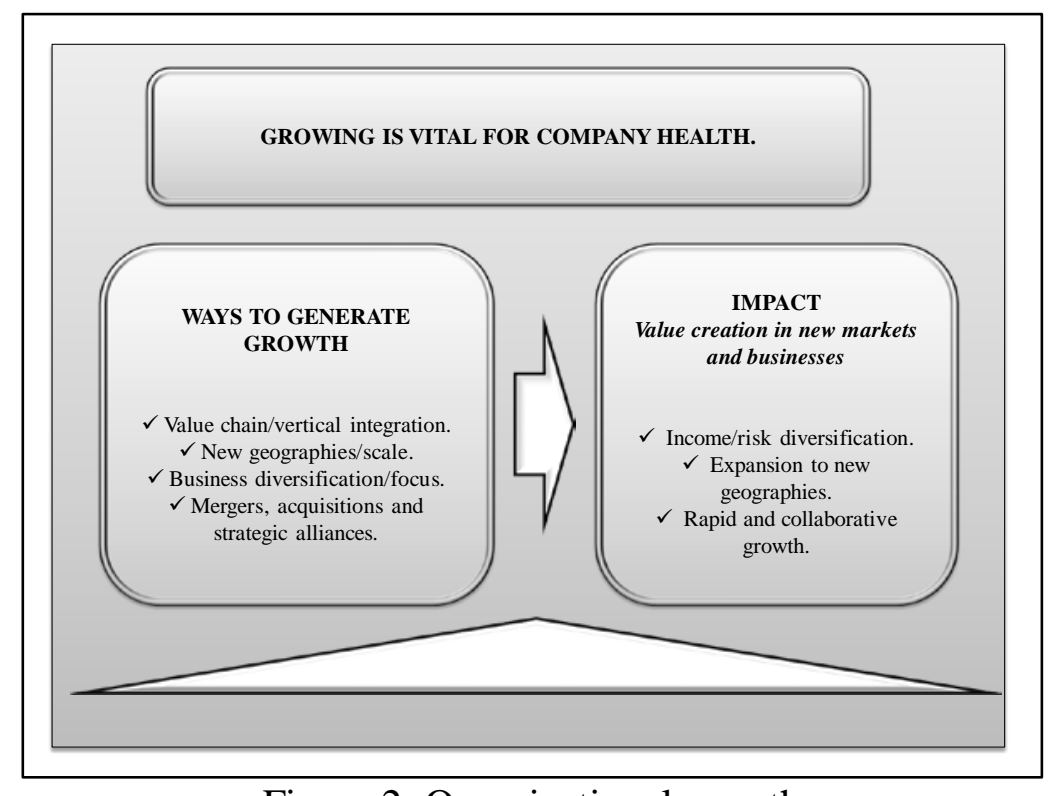

Figure 2: Organizational growth

Source: Own

\subsubsection{Value creation}

Creating value implies achieving synergies for business sustainability. In this sense, Parada Balderrama and Planellas Arán (2007) say that to create value it is needed "corporate parenting”, understood as the sum of the parts contributing to a better whole or final product. Moreover, they assert that real value creation happens when the company contributes to improve the different business unit capacities, and that businesses that do not generate value are candidates to be sold or -more frequently- disappear, since they do not offer something different to the market.

Complementing these concepts, Martínez (2011) states that:

- Value creation must be the objective of any company, not profit maximization.

- Value is generated when the benefits exceed the costs incurred; so, the goal should be to maximize profits and minimize costs.

- In order to maximize value creation and to decrease costs, it is necessary to perform an adequate value chain analysis; that is, to focus and measure processes that 
DOI: $10.14807 /$ ijmp.v12i4.1340

produce customer value. Also, suggests that there is a limitation to costs minimization as a company cannot generate benefits without costs and -in addition- the more benefits that are intended to be generated, the more resources will be required.

As a result of this section, value creation represents the fundamental objective of any organization. As it may come from internal and/or external processes, the DC chain represent an important external source, adding capacities and skills that firms currently may not have or don't want to develop. As a result, a DC can be conceived as a fundamental strategic partner, providing customer and market value.

The following Figure 3 presents the main concepts expressed regarding firms' value creation:

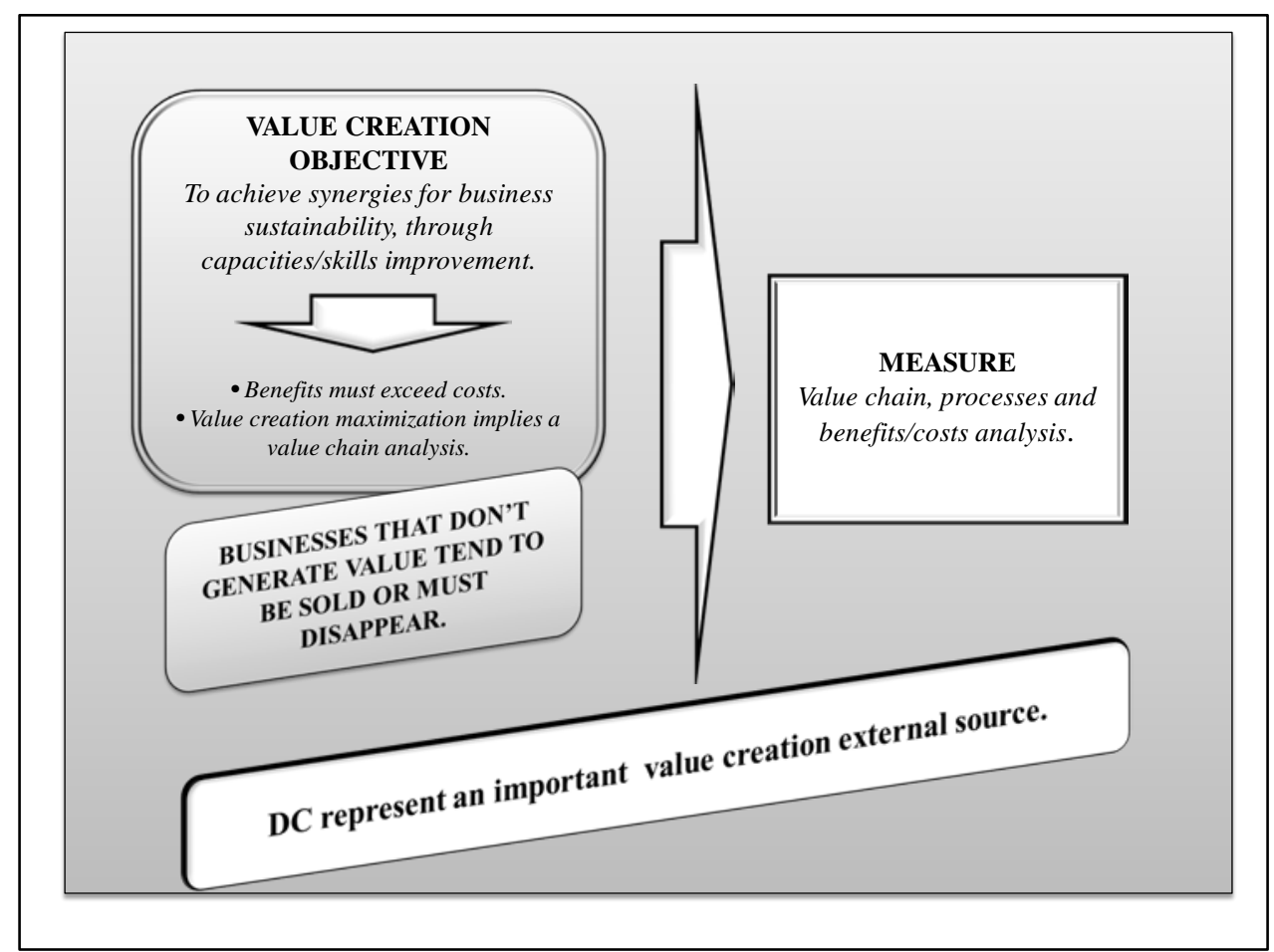

Figure 3: Value creation

Source: Own

\subsubsection{Corporate Strategy}

This concept is strictly connected to organizational growth and future business health, for which it becomes important the DC structure definition, as channels represent an important part of the strategy implementation. As a result and in the following paragraphs, will be described its importance, scope and why strategic positioning is so important for organizations. 
DOI: $10.14807 /$ ijmp.v12i4.1340

Freedman (2016) states that strategy is connected to the capacity to observe the world in the short and long terms, and in a different manner; causes and symptoms should be identified, and consequences should be prevented. In addition, López-Quesada (2017) says that it is referred to the way goals and objectives are achieved with specific tactics.

Complementing the above and according to Porter (2015), strategy differentiates a company from competitors, basing on three generic strategies: cost, differentiation and niche. Each of these strategies represents the need for a diverse organizational structure with specific characteristics.

As a consequence, firms are urged to establish adequate strategies and follow strategic planning rules to set up a differentiation in their markets. That is why, Kotler and Amstrong (2012) suggest that strategic planning must be consistent with company's mission, vision, goals and capabilities, and that tactics differ from strategies because the former encompasses shortterm actions and are subject to change, while the latter connect with the longer term and sustainable competitive advantage. As a consequence, tactics meet small specific goals, while strategy is set with a broader vision and determines how the organization's success will be achieved.

As a result, López-Quesada (2017) understands strategy as a general plan with three different kinds of planning: 1) strategic, that connects the vision, mission and values with company strategies/policies, 2) tactical, referred to strategic planning execution, following objectives, action, budget and results, and 3) operational, which uses financial, human and material resources.

\section{$\underline{\text { Strategic positioning }}$}

Porter (2015) indicates that strategic positioning helps to achieve a competitive advantage, for which differentiation from competitors becomes key. Likewise, it refers to three fundamental principles: 1) creates a unique and valuable position, 2) develops good judgment and common sense, key for decision making, and 3) is embedded in company's processes. Thus, strategic positioning emerges from three different sources:

- From the satisfaction of few needs to a large number of customers (generic cost strategy).

- From the satisfaction of a wide range of needs to few customers (generic differentiation strategy). 
INDEPENDENT JOURNAL OF MANAGEMENT \& PRODUCTION (IJM\&P)

http://www.ijmp.jor.br

v. 12, n. 4, May-June 2021

ISSN: 2236-269X

DOI: $10.14807 /$ ijmp.v12i4.1340

- From the satisfaction of a wide range of needs to a large number of customers in a specific market sector (generic niche strategy).

Also, the way in which strategic decisions are made requires further analysis. Porter says that the increasingly competitive markets lead to making decisions under extreme pressure, so that imitation seems inevitable and differentiation is a more arduous and long-term path. For this reason and in order to establish a successful strategy, suggests that risks must be taken and experiences from all organizational levels should be considered. Therefore, strategy must be democratized and shared by the vast majority of employees.

In this section, considerations were made on corporate strategy that is applicable to DC organizations. Higher levels of strategic understanding and participation will allow many more companies -and DC- to implement a strategic process in order to be successful in the increasingly competitive markets they serve, supporting business management and future growth.

The following Figure 4 shows a summary of the fundamental concepts expressed in this section:

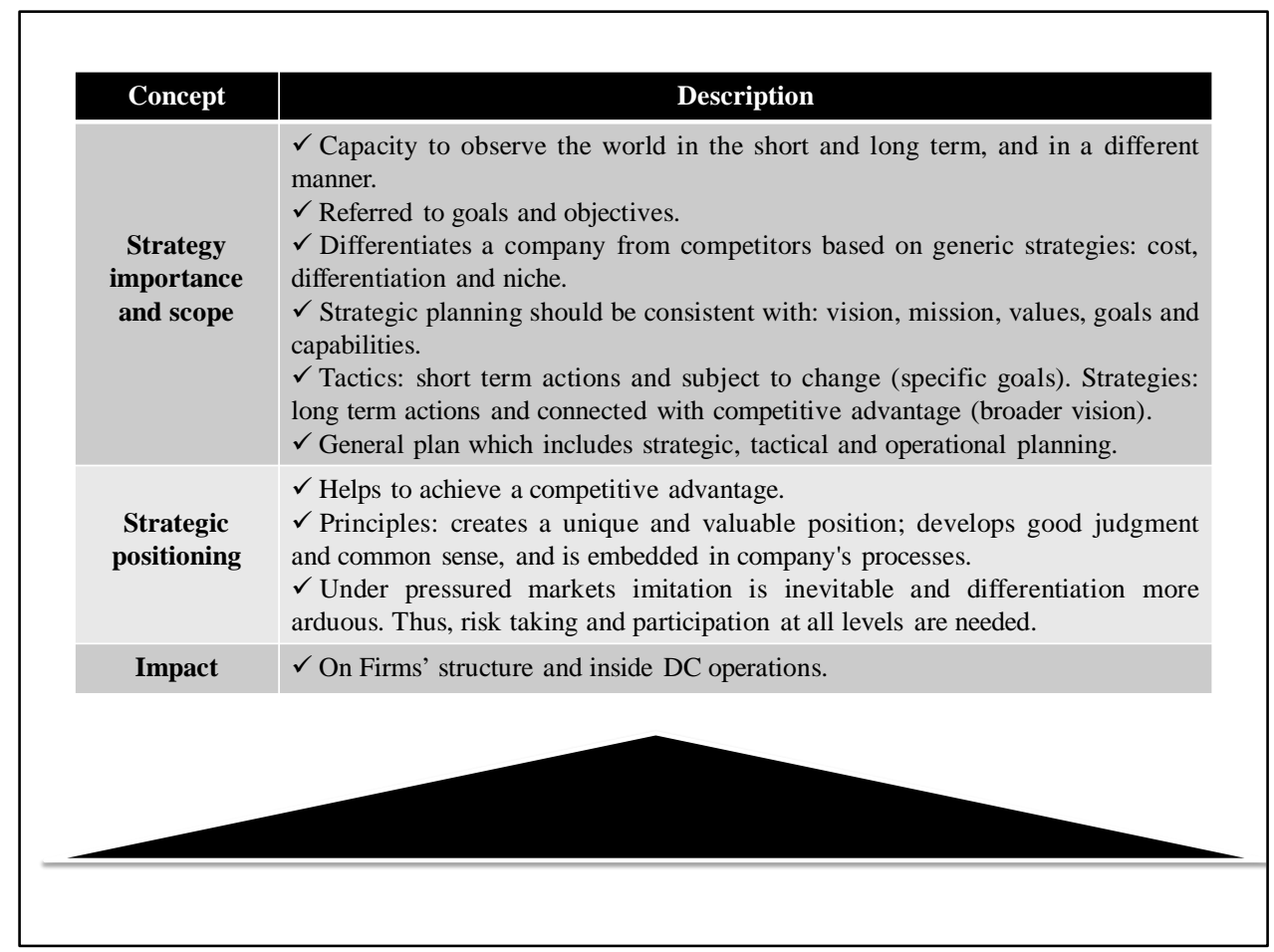

Figure 4: Strategy

Source: Own

Previously, different topics were covered connecting with corporate strategy, sustainable growth and value creation. As a result, it may be concluded that a clear and 
DOI: $10.14807 /$ ijmp.v12i4.1340

sustainable strategy becomes important to create a unique market positioning, leading to growth and value creation alternatives, vital elements in which technological firms focus their DC to add their skills and capacities in their markets. The following Figure 5 shows the basic concepts expressed before:

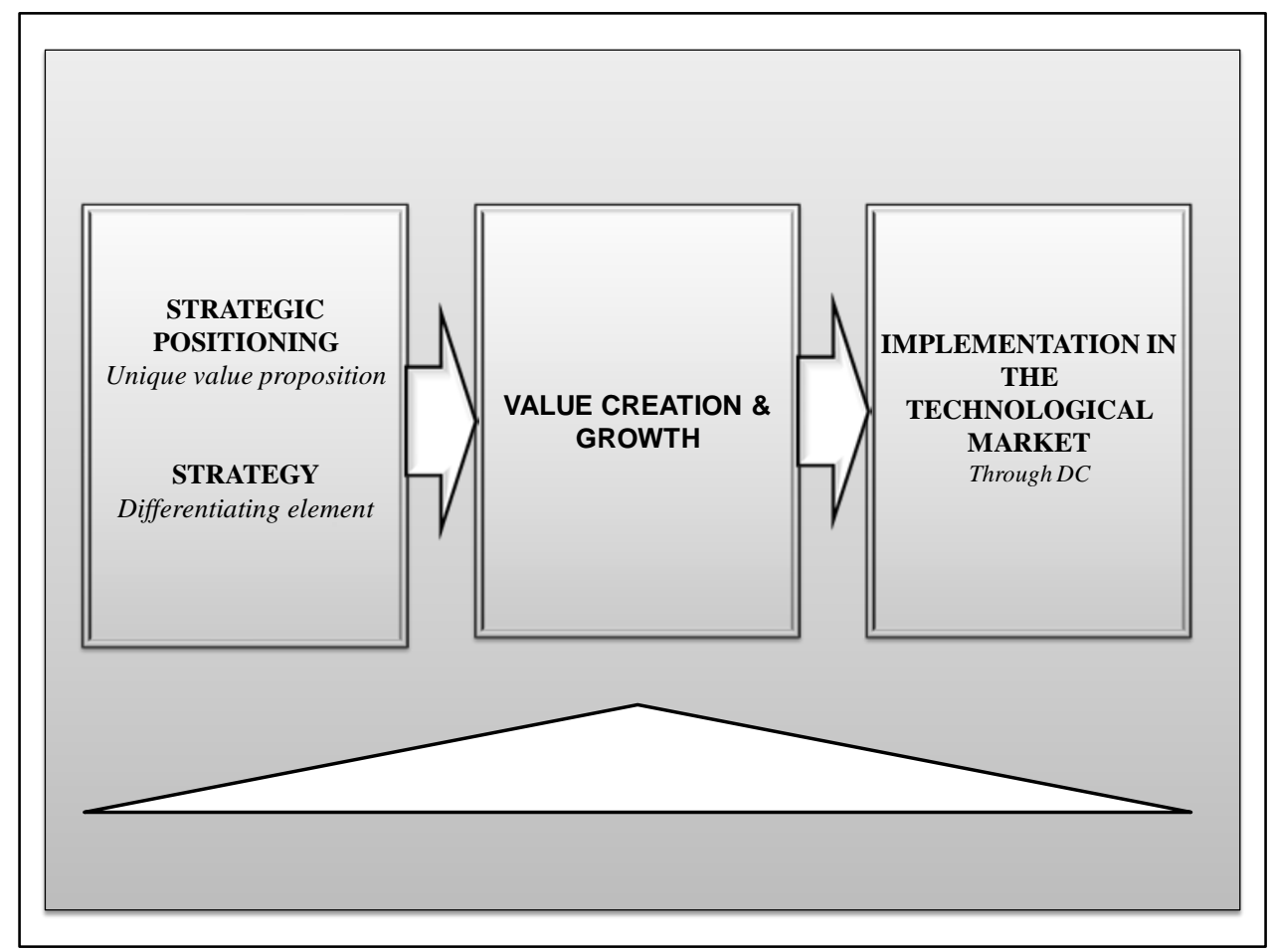

Figure 5: Strategy, growth and value creation

Source: Own

\subsubsection{Marketing}

This discipline is about establishing relationships between the firm and its customers. In this way, understanding what they want and the best way to reach them with products/services will help in designing a more effective and efficient DC network, topics that will be discussed below.

\section{Its scope and the Marketing Mix (MM)}

According to Kotler and Amstrong (2012), marketing represents the process by which companies generate value and exchange valuable relationships with their customers. They suggest that this process consists of five steps:

1) Understanding the market and customer needs.

2) Customer driven marketing strategy design.

3) Marketing program development focused on providing superior customer value. 
DOI: 10.14807/ijmp.v12i4.1340

4) Profitable and long-term relationships with customers.

5) Customer’ value capture.

The authors add that customers have needs and wants, and that demand represents wants that are supported by a purchasing power. In this sense, marketing management is related to supply a specific target market with a distinctive value proposition, which is connected to a set of benefits that the company uses to satisfy them. As a result, it is fundamental to understand which customers must be served and the best way to do it.

Complementing the prior concepts and according to Kotler and Keller (2012) and Perreault et al. (2013), marketing focuses on recognizing, finding and satisfying customers' needs, highlighting the importance of designing strategies and plans to carry out a successful marketing plan. Also, they specify the activities that determine a successful marketing management function, among which are mentioned: plans and strategy design; customer focus; communicating and granting value; and generating long-term profitable growth. In other words, they describe marketing as the process and execution of plans related to the business in general-, but specifically to the 4Ps or Marketing Mix: Product, Price, Place (distribution), and Promotion, aiming at total customer satisfaction and organizational objectives' achievement. In a deeper detail, they say that:

- Products are understood as benefits and characteristics that are offered to a customer, considering functionalities, duration, value added and quality, among others.

- Price is determined by the product total cost and is the most sensitive variable as it has a great connection with competition: a wrong pricing strategy can cause a significant impact in company sales.

- Place or distribution refers to the place where the product/service is marketed. Basically, it considers the chain that is utilized for reaching the customer's hands, from the manufacturer to the final consumer. In technology, the DC receive special consideration in this aspect.

- Promotion indicates which channels are used for customer's persuasion and communication. Basically, it has to do with the efforts that a company carries out so that its product can increase its level of acknowledgment, generating higher 
DOI: $10.14807 /$ ijmp.v12i4.1340

sales. Specifically, promotion covers advertising, personal sales, public relations and market promotions.

In conclusion, these four elements are very important for any firm as -if adequately managed- they are connected with company strategy and competitive advantage.

\section{Service marketing}

Unlike the acquisition of a tangible good, when the consumer purchases a service his/her expectations and criteria are different. Also, the experience is another new factor because it is very important the way the company interacts with consumers. According to Kotler and Armstrong (2012), people satisfy their needs and desires with products (tangibles) and services (intangibles), but products are not only limited to physical objects; they refer to any element that can satisfy a need, such as physical objects, services, and ideas. As a consequence:

- Services (intangibles) are produced by the interaction of a seller and a buyer, not in factories, and are connected with an activity or process, not with an object.

- Tangibles (goods) are maintained in stocks and ownership is transferred, but for services customers participate in their production and cannot generate stocks.

- Some services are part of a product and vice versa.

According to Kapoor et al. (2011), the products - to which the 4Ps are applied: product, price, place and promotion- are insufficient when speaking about intangibles, being necessary to add 3Ps more: people, physical evidence and processes, as follows:

- People: they play a main role in the goods and services marketing. Company success depends on actions in front of consumers for which it is necessary to foster a harmonious work environment and continuous training to achieve the desired results. Firm's values, vision and mission must be understood and shared by every employee, and -in this way- customers may have workers' perception as not only mere professionals, but as brand ambassadors. In this way employees generate empathy with consumers, understanding their needs and knowing how to best satisfy them.

- Process: it is referred to the customer service method. Consumers have expectations that must be met, and -additionally- must be equal to all customers in 
DOI: $10.14807 /$ ijmp.v12i4.1340

a standardized process and with adequate quality levels, coming from every company department.

- Physical evidence: the product/service quality must be supported by a physical evidence. This instance is of utmost importance, especially in remote sales channels, such as the internet or DC, the case of this study. Customers have certain caution when purchasing goods/services in these channels and seek support from previous buyers' experiences, gaining greater confidence while completing the transaction.

\section{$\underline{\text { Target Market (TM) }}$}

A central marketing element is represented by the TM. According to Kurtz and Boone (2013), it is understood as the set of customers on which the marketing and sales efforts of a firm are directed. As a result, the segmentation process -based on customer's behavior, geography, demographics and/or habits- becomes important to better manage the marketing mix.

In addtion, Porta (2015) says that the correct TM definition is essential so that the company's efforts are not wasted and that no firm can take every customer as a TM. Hence, there is a need to clearly define market objectives. Also, a clear TM definition does not enable potential customers from being attracted to the offer, but rather optimizes each dollar that the company directs to the market, resulting in better effectiveness and efficiency.

In order to have a better TM delimitation, the author says that the following aspects should be taken into consideration:

- Actual customers. Special attention should be paid to the reasons why they buy the products and the characteristics they have, such as demographic, geographic, psychographic and behavioral.

- Main competitors and the TM that is being served, which must be homogeneous and measurable.

- Actual company products/services, listing their strengths and weaknesses.

\section{$\underline{\text { Branding }}$}

For Razak (2020) branding comprises: 
- Every distinctive tangible and intangible asset related to the brand identity. It aims to build a consistent, differential and sustainable brand promise and experience over time.

- A work approach and a philosophy to which all the assets linked to the brands should be tied. In this sense, it is a process of building, growing, maturing and managing a brand.

- Four basic functions: strategic brand management; consumer and market knowledge; communications; and design.

Moreover, the author says that branding contributes to a promise construction and to a distinctive, relevant, complete and sustainable experience over time. It is necessary to understand that a brand is connected to emotions, feelings and perceptions that occur in consumers' minds and that are relative to a product/service. That is why it refers to a sign that is made or placed on someone or something, to make a distinction, or to denote quality or belonging. As a summary and coinciding with Kotler and Keller (2012), "brands are emotions, feelings and perceptions that occur in consumers' minds”.

As a result, Razak suggests that a brand prevails in consumers' minds, for which all types of contacts between the brand and people are very important and influential. In this regard, branding takes the brands as a starting and destination point, defining the ideal setting for their growth and building a significant meaning in peoples’ minds.

In this section, marketing was presented as a process that generates value and worthy relationships exchanges with customers. The traditional marketing mix -the 4Ps applied to tangible traditional goods- should be expanded to 7Ps when dealing with services in order to support marketing plans and strategies. Moreover, marketing management eficiency and effectiveness focus on the right target market, segmentation, control and branding, that define de ideal setting for firm's growth and builds the right values in people's minds. Its final objective refers to supplying a specific target market with a distinctive value proposition, recognizing, finding and satisfying customers' needs, wants and demands. As a consequence, an appropriate DC design and implementation scheme becomes fundamental to achieve a specific result, reaching the targeted customers.

In the following Figure 6, it is shown a summary of this section: 
DOI: $10.14807 /$ ijmp.v12i4.1340

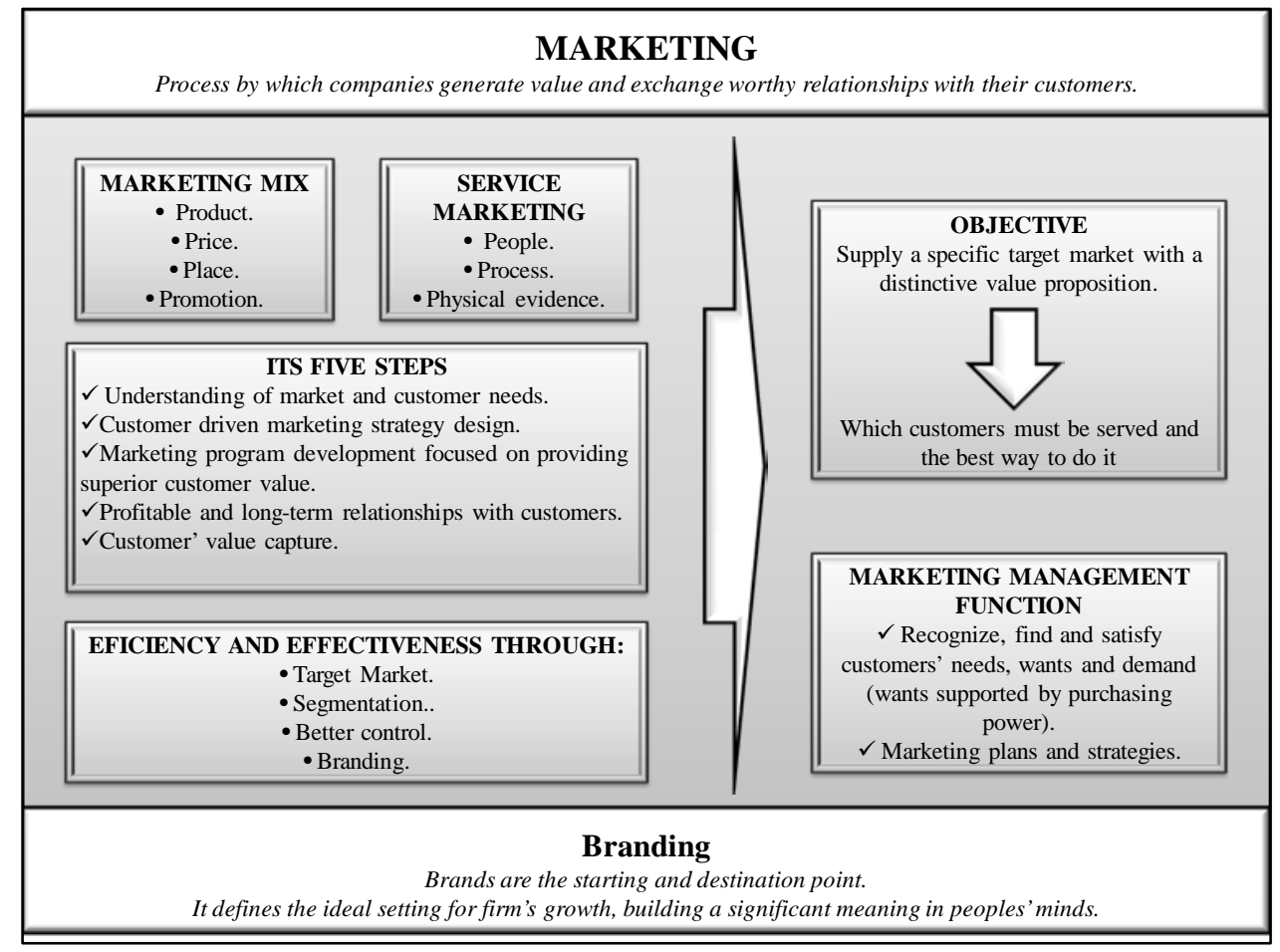

Figure 6: Marketing

Source: Own

\subsubsection{Best Practices (BP)}

BP involve delving into what others know and implemented in order to be successful in their industries. As a consequence and in this section, it is intended to synthesize some BP found, highlighting certain elements that may be seen as value added for this study.

In fact, IMMPC (2020) indicates that BP consist on a series of methodologies, systems, techniques and tools which have been applied and approved since they have reported outstanding results in large, medium and small companies. Its objectives are based on improving performance in organizations, through boosting strategic, operational and administrative processes in a methodical way.

Jiménez (2014) explains them as innovative practices that contribute to company’s performance improvement, implying knowledge accumulation, lessons learned, reflection and analysis on what can be applied or not in different situations and contexts.

Similarly, Kenton (2018) suggests them as a set of guidelines, ethics, ideas or benchmarks which are useful in different organizations. Usually, firms share information on how to implement them in an organization, although it should be said that some turn out to be trade secrets that have been legalized as "utility patents”. 
DOI: $10.14807 /$ ijmp.v12i4.1340

The challenges presented in other industries may well be considered as a starting point for understanding what may be applied in technology and telecommunications. Through the study that Murguia and Correa (2013) made on the insurance industry, they establish certain challenges that are important to take into account when developing a company's distribution network, especially in the technological/telecommunications industry, such as:

- Consider changes in the country's regulatory framework and new technologies that could generate business modifications.

- DC credentials and certifications must be aligned with company strategy to have an impact on the market. Certifications must be administered by an independent entity outside the company: specifically and in the technological market, the firm that is mostly chosen is Prometric ${ }^{2}$.

- Internationally developed BP must nurture firms and enhance their operation.

- Encourage innovation, coming from a deeper customer interaction.

- Compensation and incentive schemes have a strong impact on DC brand loyalty and on the priority that the brand will have within their operation.

- Business growth comes from recruiting new DC.

- Training sessions should go beyond technical matters. That is why additional business-related skills should become an important element in the training process.

- Firms should provide useful tools to their DC, such as certifications, training, and business and technical support.

In this section, were discussed some of the BP that are recommended for a more effective and efficient customers' reach, which are summarized in the following Figure 7:

${ }^{2}$ Prometric: Educative USA firm that administers specific tests and more than thousands of exams, in more than 160 countries of the world. 
DOI: $10.14807 /$ ijmp.v12i4.1340

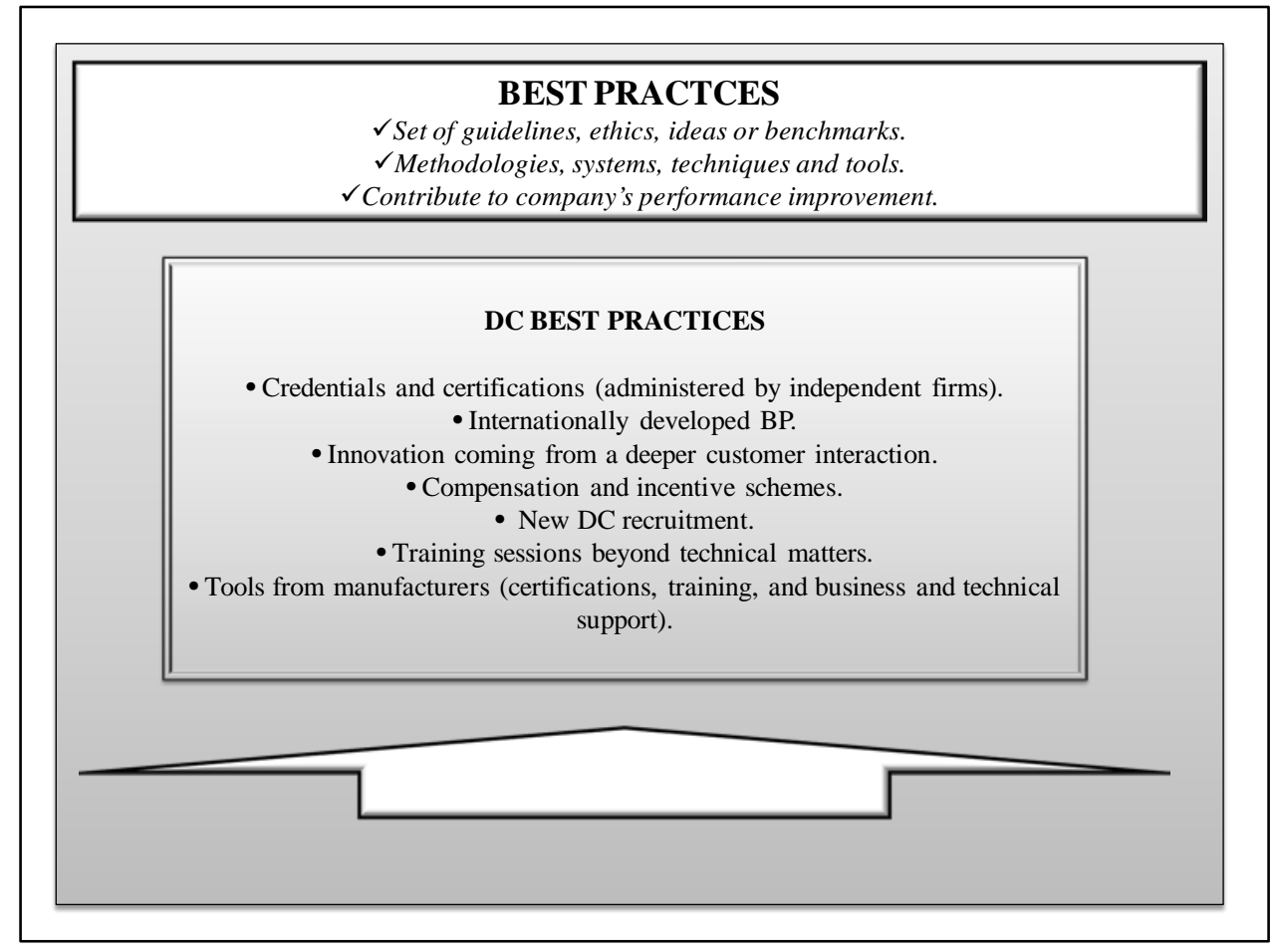

Figure 7: Best Practices (BP)

Source: Own

\section{FIELD WORK}

The field work that supports the present study consists of three executives' interviews ${ }^{3}$ that helped to better understand the DC networks operation in Argentina. For more than 20 years, they have had an exposure on this matter at different Director/Management levels, and for important technological multinational firms, with responsibilities in the Latin American region.

Thanks to these semi-structured interviews -that were held between Feb.-Apr., 2020 and lasted approximately one hour each- it was possible to deepen on the manufacturer-DC relationship and in different market characteristics. The basic questions used are detailed as follows:

- What is the importance that DC have in the technological business?

- What are the manufacturers' benefits when implementing an adequate distribution chain?

- What are the DC's benefits when managing a brand?

3 The executives asked to keep their names and the companies for which they worked as confidential. 
DOI: $10.14807 /$ ijmp.v12i4.1340

- Do you see DC improvement opportunities in Argentina?

In the following paragraphs and ordered in diverse titles it is shown a summary of what these executives contributed.

\subsection{Channel marketing models}

One of the main DC benefits was connected to the geographic coverage, approaching the largest number of customers in the most effective possible way. A vast DC network implied territorial coverage and aimed for brand awareness growth. In addition, they produced huge savings in a large sales force investment when covering a territory.

There was a need for two different kinds of organizations in the market: the wholesalers and the DC. The formers purchased computer products directly from the manufacturer and then sold them to the DC, which provided specific end customers' requirements response. The latter had a complementary role connected mainly with:

- Bringing the brand and its products closer to final customers.

- Providing manufacturers with greater capillarity and reach in certain places that were difficult for the company and the wholesaler. Moreover, it was important a close contact between the manufacturer and the DC, since working together many improvement opportunities could be individualized.

Additionally, were mentioned three market coverage strategies:

1) Direct: the manufacturer had a direct relationship with end customers, not needing a DC involvement at all. So, manufacturer's commercial executives provided direct assistance to end customers.

This model was cost-effective, but it might have potential for loss of coverage. Example: Dell Computers Inc.

2) Indirect: the brand had an indirect relationship with end customers, requiring the DC intervention in every transaction. In this case, the commercial executives coordinated and supervised DC activities and actions.

This model had better coverage possibilities, not being competitive when supplying medium and big customers. Example: Hewlett Packard. 
DOI: $10.14807 /$ ijmp.v12i4.1340

3) Hybrid: There was a combination of assistance to end customers, as some would be served directly and others through a DC. As a result, it was needed a clear manufacturer's definition of which customers would be served directly and which indirectly, considering the benefits and costs in each case.

It was raised as the most flexible and adaptable model to customers' requirements and needs. Example: Oracle Corp.

There was a coincidence that the most compatible strategy for the technology industry was the hybrid model as it synthesized the greatest manufacturer's flexibility to approach the market effectively.

In addition, they agreed that the consultative sales -done by some DC or directly by the brand- was the most appropriate approach in bigger and more complex projects.

Thus and in certain cases, a CD could be considered an appropriate vehicle to reach different final customers in Argentina.

In turn, some experts pointed out DC skills and resources' shortages to be able to carry out some value added businesses, which involved more complex solutions tailored to end customer requirements. That is why manufacturing companies provided a specific support and plans to this kind of DC not to lose them.

\subsection{Improvement opportunities}

Out of what some executives suggested, there were different areas in which manufacturers-DC relationships could be improved, like:

- Better communicate the manufacturer's objectives to the DC in order to let them understand the benefits that the brand could offer and its future development plans.

- Offer higher DC profitability to privilege manufacturer's over competitor's products and services. To better develop this area it was important to enhance training and business strategies, such as promotions, incentives and demand generation for end customers.

- Improve incentive programs -conceived as market development initiatives related to the medium-term- and promotions -oriented to the short-term. It was required to adequately coordinate manufacturers-DC actions. 
DOI: $10.14807 /$ ijmp.v12i4.1340

- Reduce manufacturer-DC conflicts (called vertical channel conflicts) on end customers demand generation. From one side, the DC requested to the brand this type of demand generation, but -from the other side- the manufacturers expected from the DC to do so. Also and in the case of the server4 business, manufacturing companies understood that the DC should advise the end customer on which server could better satisfy their needs and -also- transmitted the product value. These conflicts deepened as each party was focused on their own points of view about who was responsible on end user demand generation. The basic idea that was raised by some experts was referred to visualize the DC as a brand evangelizer and as a manufacturer's partner in the market.

For Argentina, it was remarked that there were firms that acted as a useful help and as a moderator for commercial initiatives in the manufacturer-DC relationship, like IT Sitio, a local Argentinean firm serving important technological customers.

At the same time, it was suggested a difference between generating demand in the massive businesses -understood as products for daily use and for sale in large quantities, for which $80 \%$ of end user demand was generated by the brand- and in the value added business, which corresponded mostly to the DC.

- Opportunity Registration process improvement: represents a DC investment protection in certain end customers when two or more DC were working for the same business proposal. Enhancing this process in terms of transparency and opportunity registration could help the manufacturer-DC relationship and improve the entire customer development process.

- Refine business training -in general- but specifically on management and marketing topics, including product, services and support. In other words, a better business understanding and involvement could bring greater sales and increased profitability for the whole network.

In the following Figure 8, it is shown a summary of this section:

${ }^{4}$ Servers: Dedicated computer systems with client-server architecture, capable of meeting customer requirements. They usually provide essential services within a network, such as databases, archives, mail, web printing, applications and games, among others. 
DOI: $10.14807 /$ ijmp.v12i4.1340

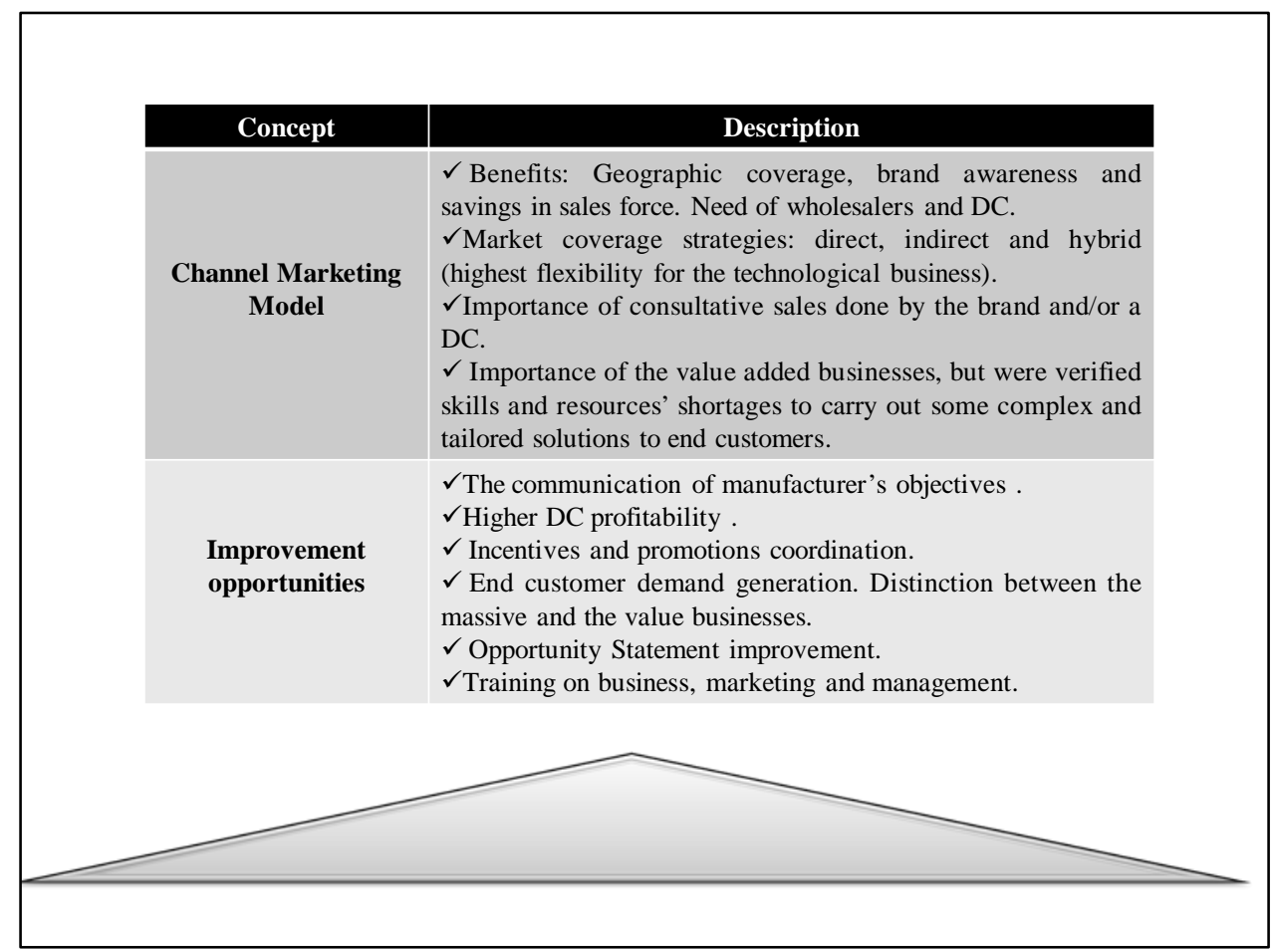

Figure 8: Field work

Source: Own

\section{CONCLUSIONS}

Manufacturing firms were utilizing various distribution models; among them the hybrid one was remarked by experts as the most suitable in the technological arena, since it was producing the highest levels of flexibility and profitability. Also and as these firms needed the best market coverage, they had to identify those customers that needed direct attention and the ones that should be supported by a DC, depending on each business requirements and needs.

As a result of this investigation, the following conclusions -organized in different titleswere reached:

\subsection{About Distribution Channels (DC)}

In the Theoretical Framework (TF) it is said that DC are used as vehicles to deliver products/services from the manufacturing company to the final customers, being brand's evangelizers in the market. Long DC and hybrid models are mostly used in the technological arena, improving the commercial reach. In addition, it becomes important to make the best use of the new DC that emerge.

Their main benefits correspond to helping final customers with an overall solution -that may include hardware, software and services- and a good purchase experience. From the 
DOI: $10.14807 /$ ijmp.v12i4.1340

manufacturer's side, it is required to focus on cost optimizations, channel efficiencies and vertical conflicts reduction.

Coinciding with what was said before the Field Work (FW) revealed that the DC main benefits were connected to a better geographic coverage, brand awareness and savings in increasing sales force. For those reasons, the importance of consultative sales and different market coverage strategies were pointed out. In this sense, the interviewees said that the hybrid coverage used by manufacturers in this industry was giving the highest flexibility and profitability.

Additionally and in the TF, remote channels and online platforms represent big challenges for this industry, despite physical channels are still important because of the need for face to face attention and product testing at the time of purchase. Other challenge that was indicated in the FW corresponded to the Opportunity Registration process improvement that adequately managed- could protect the DC investment in certain customers.

Different authors said that -for manufacturers- there was a need to identify and understand the whole DC network value and, specifically, which were the top channels by category to partner and grow together. As a result, it was fundamental to work on the optimal channel level mix and sales, on the end customer experiences with the brand and on the specific actions required on channel mix.

Moreover, they remarked their importance for business growth through opportunities in the technology/cloud-based businesses and in SMB that needed more personalization and value added focus in order to fight against product commoditization. It was suggested to find synergies, collaboration and communication among the diverse constituents of this business to help on market development.

\subsection{About business factors in the technological industry}

In the TF it is suggested that the DC represent a fundamental value creation external source for the technological industry manufacturers, helping on:

Growth, as they becomes essential for organizational health through new markets and businesses expansion (better coverage), diversifications and collaborations.

Value creation, coming from the whole value chain and the processes that are used. It is the result of synergies for business sustainability through capacities/skills improvement. As a consequence, businesses that are incapable of generating value tend to be sold or disappear. 
DOI: $10.14807 /$ ijmp.v12i4.1340

From another perspective and for manufacturers, some interviewed experts said that an adequate DC training was one of the bases for differentiation and value creation. But from the DC side, they noted their key role in providing integral hardware and software solutions to end customers, for which knowledge and support constituted their main value creation sources. In this sense, it was admitted that value added was important in business, but were verified skills and resources' shortages when carrying out some end customer complex and tailored solutions.

Additionally, the FW disclosed some improvement opportunities, such as in the communication of manufacturer's objectives, higher DC profitability, incentives and promotions coordination, end customer demand generation, and business, marketing and management training.

In the TF it is said that strategy and marketing are important areas in which a special focus should be given for DC’s network/manufacturers better operation.

Differentiated long and short term initiatives must be aligned to achieve goals and objectives. Wholesalers -that purchase big quantities- and value added DC -focused on specific businesses- should follow cost and differentiation strategies, respectively. Strategic focus and tactical and operational plans should enhance market opportunities and results, achieving competitive advantage.

Creating a unique value proposition and excelling customer processes represent a way to get away from imitation and commoditization. For that, strategy formulation should be democratized in many more organizations -manufacturers and DC- to serve as a vehicle for value creation and growth alternatives identification. Finally and to have a better implementation in the technological market, the DC should be part of its definition and implementation. In addition, interviewees insisted that it was also necessary -for a better market impact- to make a distinction between DC for the massive and the value added businesses.

Additionally, marketing -with the 7Ps for services- was presented as a process by which firms generate value and exchange worthy customers relationships. Its objective is to supply a specific target market with a distinctive value proposition, becoming fundamental to understand which customers must be served and the best way to do it. Brands must build a significant meaning in peoples' minds and be the base for firm’s growth.

As a result, effective business environments should direct strategy and marketing plans to frame adequate settings for organizational positioning and growth, creating long term customer value. 
DOI: 10.14807/ijmp.v12i4.1340

Finally, best practices in the DC operation should be considered as a way to evolve to new performance levels, including credentials/certifications (administered by independent firms); internationally developed business practices; innovative procedures/processes coming from a deeper customer interaction; improved compensation/incentive schemes; new DC recruitment; comprehensive training sessions; and better tools from manufacturers (certifications, training, and business and technical support).

\section{PROPOSAL}

Currently, technological industry manufacturers rely significantly on their DC network. That is why and from what was stated in this investigation, a proposal for manufacturers-DC operation improvement could comprise the following aspects:

\subsection{Business strategy, growth and value creation}

Strategy, marketing and specific plans should be collaboratively developed between the brand and the DC in order to achieve competitive advantages. Each organization should be part of a comprehensive operational future vision and perspective for improvement, differentiating short and long term initiatives. As a result, the communication and sharing of manufacturer's objectives with the DC network becomes the fundamental starting point on this matter.

Growth and value creation are fundamental for organizational health and sustainability, for which there should be considered perspectives on new markets/businesses, product diversification, and business processes improvements. Opportunities in the technology/cloudbased businesses and in SMB should be part of the strategic thinking process.

Another focal point in this aspect, referrers to develop in both organizations manufacturers and DC- the need for more personalization and value added focus to fight against product commoditization. Market development should come from finding synergies, collaboration and communication among the diverse participants. At the end of a democratic strategic formulation, each DC should have a detailed plan that should respond to building a unique value proposition and excel on customer processes and experiences.

\subsection{Business model, demand generation and incentives/promotions}

Long and hybrid distribution models should be reviewed, focusing on which are the most suitable channels for market coverage and the best way to serve each final customer. In this regard, new DC must be adequately catalogued and assigned to end customers, and adequate DC retention plans should be put in place. 
DOI: $10.14807 /$ ijmp.v12i4.1340

The 7Ps of service marketing should be directed to exchange worthy customer relationships, and a customer profitability analysis should be performed to determine if they are being served in the best way possible and in the most efficient/effective manner.

End customer demand generation is a key conflict that should be resolved to appropriately apply the manufacturers and DC efforts to the market.

Customer purchase experience should be seen as the sum of different factors, which include: brand strength and support; profitability; customer/market focus, training, collaboration, communication, problem solving, cost optimizations, channel efficiencies and vertical conflicts reduction.

Remote channels and online platforms should be implemented in order to serve the most quantity of customers and/or to give the best information in a timely manner.

Periodic reviews on the Opportunity Registration processes should be performed as a way to protect key customers investments made by the DC. The customer perspective should be the point of departure for this analysis, distinguishing among value added/consultative sales and massive clients.

As a result, it is necessary to identify and understand: a) the whole DC network value, b) the top channels in each category to partner and grow together, c) the optimal channel level mix and sales, d) end customer needs and experiences, and e) specific actions required on channel mix.

DC incentives and promotions must serve as a source for motivation and market focus. That is why it is necessary an adequate collaboration to identify and coordinate these programs.

The brand should periodically survey customers to understand the attributes that they recognize and the meaning it has in their minds.

\subsection{Training/education initiatives}

Comprehensive training/education initiatives -that include manufacturers and DCshould be developed as they are a core aspect for differentiation and value creation. Their main objective should be directed to resolve: a) resource's shortages/mismatches, b) complex and tailored solutions, and c) strategic, marketing and management issues. 
DOI: $10.14807 /$ ijmp.v12i4.1340

Specific trainings for different organizational levels should also be considered. For example, employees that are in charge of physical channels should be trained in customer service and products to assure better purchase possibilities, and CD's executives in leadership and change management, among others.

\subsection{Best Practices}

A constant market best practices analysis should be performed, determining if there is a need to review strategies, innovations, practices, procedures, processes, certifications, credentials and/or tools (like end customers visits together between manufacturer and DC). Benchmarks against other industries must be included.

This work showed different DC facets of the technological industry and possible improvement aspects in this type of operations. Management focus on this complex and exiting environment could bring better performance levels for the organizations that configure this multi-dimensional process.

\section{REFERENCES}

Avrane-Chopard, J.; Bourgault, T.; Dubey, A.; Moodley, L. (2014). Big Business in small business: Cloud services for SMB's, McKinsey Quarterly.

Balderrama, P. P., \& Arán, M. P. (2007). ¿Qué es estrategia corporativa?, ESADE Business School, Harvard Deusto Business Review, Recovered from http://ocw.uniovi.es/pluginfile.php/2669/mod_resource/content/1/Lectura_sobre_Estrategia_ Corporativa.pdf, on 04/18/2020.

Berland, M., \& Furtado, B. (2015). Why yesterday's channel practices won't win over emerging market customers, McKinsey Quarterly, Recovered from https://www.mckinsey.com/business-functions/marketing-and-sales/our-insights/whyyesterdays-channel-practices-wont-win-over-emerging-market-consumers, on 04/13/2020.

Caylar, P., Dmitriev, M., Fletcher, B., \& Gieder, P. (2014). Change the channel: A new multi-touch portfolio, McKinsey Quarterly, Recovered from https://www.mckinsey.com/industries/technology-media-and-telecommunications/ourinsights/change-the-channel-a-new-multi-touch-point-portfolio, on 03/12/2020.

Del Molino, C., Díaz, A., \& Martins, D. (2014). Lost in translation: the challenge of global channel and customer management, McKinsey Quarterly, Recovered from https://www.mckinsey.com/industries/retail/our-insights/lost-in-translation-the-challenge-ofglobal-channel-and-customer-management, on 03/14/2020.

Duarte, B., Nimal, M., \& Rudolph, S. (2015). Recall Channel Management, McKinsey Quarterly.

Freedman, L. (2016). Estrategia, Editorial La Esfera de los Libros, Madrid, España. González, R. M. (2014). Marketing en el siglo XXI, Ediciones Centros Estudios Financieros, Madrid, España. 
IMMPC - Instituto Mexicano de Mejores Prácticas Corporativas (2020). ¿Qué son las mejores prácticas corporativas?, Recovered from http://www.immpc.org.mx/mejorespracticas-corporativas, on 04/19/2020.

Jiménez, D. (2014). ¿Buenas o Mejores Prácticas?: La diferencia que nadie te contará, Recovered from https://www.pymesycalidad20.com/mejores-practicas-diferencia.html, on 03/19/2020.

Kapoor, R., Paul, J., \& Halder, B. (2011). Services Marketing: Concepts \& Practices, Tata McGraw Hill Education Private Limited, New Delhi, India.

Kenton, W. (2018). Best Practices, Recovered from https://www.investopedia.com/terms/b/best_practices.asp, on 04/20/2020.

Kotler, P., \& Amstrong, G. (2012). Marketing, Ediciones Pearson, México.

Kotler, P., \& Keller, K. (2012). Dirección de Marketing, Ediciones Pearson, México.

Koulopoulos, T. (2014). Navegar en la nube, Editorial Océano, México.

Kurtz, D.; Boone, L. E. (2013). Contemporary Marketing, South-Western Cengage Learning, Mason, OH, USA.

Longenecker, J., Moore, C., Palich, L., \& Hoy, F. (2012). Administración de pequeñas empresas, Cengage Learning, México.

López-Quesada, A. (2017). Estrategias de diferenciación, Ediciones ESIC, Madrid, España. Martínez, J. B. (2011). El valor de una empresa y la creación de valor de esa empresa, Recovered from file://C:/Users/.\%C2\%B4\%C2\%BF/Downloads/DialnetElValorDeUnaEmpresaYLaCreacionDeValorEnEsaEmpresa-3816159.pdf, on 04/18/2020. Murgia, C. I.; Correa, A. C. (2013). Convención Aseguradores, XXIII Congreso, México. Peris, S. M., Guerrero, F. P., \& L’Hermie, C. (2008). Distribución comercial, ESIC, Madrid, España.

Perreault Jr., W., Cannon, J., \& Mccarthy, E. J. (2013). Basic Marketing, Mc Graw-Hill Higher Education, New York: USA.

Porta, M. (2015). How to define your target market, Inc.com, Recovered from https://www.inc.com/guides/2010/06/defining-your-target-market.html, on 04/19/2020.

Porter, M. (2015). Estrategia competitiva, Editorial Patria, México.

Razak, A. (2020). Qué es y para qué sirve el branding?, Branfluence, Recovered from https://www.branfluence.com/que-es-branding/, on 04/19/2020.

Selva, J. P., \& Conde, E. R. (2013). Dirección de Marketing: variables comerciales, Editorial Club Universitario, San Vicente, España. 